\title{
Chromium immobilization by extra- and intraradical fungal structures of arbuscular mycorrhizal symbioses
}

\section{Songlin $\mathrm{Wu}^{\mathrm{a}}{ }^{\mathrm{b}, \mathrm{c}}$, Xin Zhang ${ }^{\mathrm{a}}$, Yuqing Sun ${ }^{\mathrm{a}, \mathrm{b}}$, Zhaoxiang $\mathrm{Wu}^{\mathrm{a}}{ }^{\mathrm{b}}$, Tao $\mathrm{Li}^{\mathrm{a}}$, Yajun $\mathrm{Hu}^{\mathrm{a}, \mathrm{d}}$, Jitao Lv ${ }^{\mathrm{e}}$, Gang Li ${ }^{\mathrm{e}}$, Zhensong Zhang ${ }^{\mathrm{e}}$, Jing Zhang ${ }^{\mathrm{f}}$, Lirong Zheng ${ }^{\mathrm{f}}$, Xiangjun Zhen ${ }^{\mathrm{g}}$, Baodong Chen ${ }^{\mathrm{a}, *}$}

a State Key Laboratory of Urban and Regional Ecology, Research Center for Eco-Environmental Sciences, Chinese Academy of Sciences, Beijing, 100085 People's Republic of China

${ }^{\mathrm{b}}$ University of Chinese Academy of Sciences, Beijing, 100049, People's Republic of China

${ }^{\mathrm{c}}$ Department of Environmental Geosciences, Faculty of Environmental Sciences, Czech University of Life Sciences Prague, Kamycká 129, Prague 6-Suchdol 165 21, Czech Republic

${ }^{\mathrm{d}}$ Key Laboratory of Agro-ecological Processes in Subtropical Region, Institute of Subtropical Agriculture, Chinese Academy of Sciences, Changsha, 410125, People's Republic of China

e State Key Laboratory of Environmental Chemistry and Ecotoxicology, Research Center for Eco-Environmental Sciences, Chinese Academy of Sciences, Beijing 100085, People's Republic of China

${ }^{\mathrm{f}}$ Beijing Synchrotron Radiation Facility, Institute of High Energy Physics, Chinese Academy of Sciences, Beijing 100049, People's Republic of China

${ }^{g}$ Shanghai Synchrotron Radiation Facility, Shanghai Institute of Applied Physics, Chinese Academy of Sciences, Shanghai 201204, People's Republic of China

\section{H I G H L I G H T S}

- $\mathrm{Cr}$ immobilization in AM symbioses revealed by SEM-EDS, STXM and XAFS.

- EPS like particles formed on fungal surface upon $\mathrm{Cr}(\mathrm{VI})$ stress.

- $\mathrm{Cr}(\mathrm{VI})$ was reduced to mainly $\mathrm{Cr}(\mathrm{III})-$ phosphate analogues on fungal surface.

- $\mathrm{Cr}$ can be retained by the intraradical fungal structures in mycorrhizal roots.

\section{A R T I C L E I N F O}

\section{Article history}

Received 1 February 2016

Received in revised form 4 May 2016

Accepted 5 May 2016

Available online 6 May 2016

\section{Keywords:}

Arbuscular mycorrhizal fungi

Chromium

SEM-EDS

STXM

XAFS
G R A P H I C A L A B S T R A C T

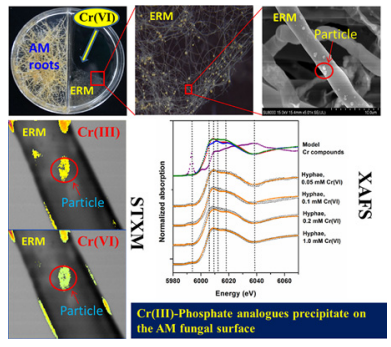

\section{A B S T R A C T}

Arbuscular mycorrhizal (AM) fungi can enhance plant $\mathrm{Cr}$ tolerance through immobilizing $\mathrm{Cr}$ in mycorrhizal roots. However, the detailed processes and mechanisms are unclear. The present study focused on cellular distribution and speciation of $\mathrm{Cr}$ in both extraradical mycelium (ERM) and mycorrhizal roots exposed to $\mathrm{Cr}(\mathrm{VI})$ by using field emission scanning electron microscopy equipped with energy dispersive X-ray spectrometer (FE-SEM-EDS), scanning transmission soft X-ray microscopy (STXM) and X-ray absorption fine structure (XAFS) spectroscopy techniques. We found that amounts of particles (possibly extracellular polymeric substances, EPS) were produced on the AM fungal surface upon $\mathrm{Cr}(\mathrm{VI}) \mathrm{stress}$, which contributed greatly to $\mathrm{Cr}(\mathrm{VI})$ reduction and immobilization. With EDS of the surface of AM fungi exposed to various $\mathrm{Cr}(\mathrm{VI})$ levels, a positive correlation between $\mathrm{Cr}$ and $\mathrm{P}$ was revealed, suggesting that phosphate groups might act as counter ions of $\mathrm{Cr}$ (III), which was also confirmed by the XAFS analysis. Besides, STXM and XAFS analyses showed that $\mathrm{Cr}(\mathrm{VI})$ was reduced to $\mathrm{Cr}(\mathrm{III})$ in AM fungal structures

\footnotetext{
* Correspondence to: 18 Shuangqing Road, Haidian District, Beijing 100085, People’s Republic of China.

E-mail address: bdchen@rcees.ac.cn (B. Chen).
} 
(arbuscules, intraradical mycelium, etc.) and cell walls in mycorrhizal roots, and complexed possibly with carboxyl groups or histidine analogues. The present work provided evidence of $\mathrm{Cr}$ immobilization on fungal surface and in fungal structures in mycorrhizal roots at a cellular level, and thus unraveled the underlying mechanisms by which AM symbiosis immobilize $\mathrm{Cr}$.

(c) 2016 Elsevier B.V. All rights reserved.

\section{Introduction}

Chromium $(\mathrm{Cr})$ is one of the common elements that exist in the natural environment [1]. It is widely used in electroplating, leather tanning, pigment production, etc. [1], while industrial utilization of $\mathrm{Cr}$ could potentially lead to $\mathrm{Cr}$ discharge into the environment resulting in $\mathrm{Cr}$ contamination [2]. $\mathrm{Cr}$ is possibly essential for human beings and animals, but toxic to all living organisms if present at an excessive level [1,2]. There are two stable $\mathrm{Cr}$ species, hexavalent chromium $[\mathrm{Cr}(\mathrm{VI})]$ and trivalent chromium $[\mathrm{Cr}(\mathrm{III})]$, of which $\mathrm{Cr}(\mathrm{VI})$ is more toxic and mobile than $\mathrm{Cr}(\mathrm{III})$ [2]. Excessive $\mathrm{Cr}$, especially $\mathrm{Cr}(\mathrm{VI})$ can pose detrimental effects on plant growth through restraining nutrient acquisition, causing oxidative damage, and even DNA damage etc. [3].

In natural ecosystem, plants usually interact with various soil microorganisms, among which arbuscular mycorrhizal fungi (AMF) are one of the most ubiquitous soil fungi that can form symbiosis with plants [4]. AMF provides host plants with mineral nutrients (such as phosphorus) and in return receive carbohydrates from plants. AMF can also enhance plant resistance to various biotic and abiotic stresses, such as drought [5], salinity [6], pathogen infection [7], and heavy metal contamination [8-11], etc. It has been documented that arbuscular mycorrhizal (AM) symbiosis also takes an active part in relieving plant $\mathrm{Cr}$ toxicity [12,13]. For instance, our previous work demonstrated a positive role of AMF in $\mathrm{Cr}$ tolerance of both dandelion (Taraxacum platypecidum Diels.) and bermudagrass [Cynodon dactylon (Linn.) Pers.] [14]. However, little information is available towards the underlying mechanisms.

One explanation is that AM symbiosis can assist in plant $\mathrm{P}$ acquisition, and thus improve plant growth and its $\mathrm{Cr}$ tolerance. This is confirmed by our previous study showing a higher P concentration in mycorrhizal dandelion compared with nonmycorrhizal dandelion under $\mathrm{Cr}(\mathrm{VI})$ contamination [14]. Another explanation is the direct immobilization of $\mathrm{Cr}$ by AM structures such as spores, extraradical mycelium (ERM), intraradical mycelium, arbuscules, etc. Previous studies have shown immobilization of Cd [15], Cu [16], Zn [17] and U $[18,19]$ by AMF structures. Similarly, AMF structures may also immobilize quantities of $\mathrm{Cr}$, reduce $\mathrm{Cr}$ transport to host plants, and thus relieve plant $\mathrm{Cr}$ toxicity. In fact, we have recently confirmed that ERM can take up and transport $\mathrm{Cr}$ to mycorrhizal roots, but restrain $\mathrm{Cr}$ translocation to shoots, and thus contributes to $\mathrm{Cr}$ immobilization in roots [20]. And we further found that ERM can immobilize a significant amount of $\mathrm{Cr}$ in root organ culture system [21]. However, the detailed processes and mechanisms underlying the $\mathrm{Cr}$ immobilization by AMF are still unresolved. In our recent study [21], we found that even when metabolically inhibited by 2, 4-dinitropheno or formaldehyde, AMF could still immobilize significant amounts of $\mathrm{Cr}$ (mainly in the form of $\mathrm{Cr}$ (III)-phosphate analogues), which suggests that $\mathrm{Cr}$ may aggregate on fungal surface [22]. Besides, similar to Cd [15], Cr may also be retained in intraradical fungal structures (e.g. intraradical mycelium, arbuscules etc.), resulting in little $\mathrm{Cr}$ translocation to plant cytoplasm, by which AMF relieves $\mathrm{Cr}$ phytotoxicity. However, solid evidence is still needed to test these hypotheses.

Therefore, the present study aimed to test if $\mathrm{Cr}$ could be immobilized on fungal surface and in the intraradical fungal structures of AM symbioses. A couple of complementary microscopic and spectroscopic techniques have been employed to investigate cellular localization and speciation of $\mathrm{Cr}$ in AMF and mycorrhizal roots. Field emission scanning electron microscopy equipped with energy dispersive X-ray spectrometer (FE-SEM-EDS) was adopted to investigate morphological and elemental composition changes of AMF mycelium and spores exposed to $\mathrm{Cr}(\mathrm{VI})$. Synchrotron radiation based X-ray absorption fine structure (XAFS) spectroscopy was used to determine $\mathrm{Cr}$ speciation in AMF hyphae [23]. Besides, scanning transmission soft X-ray microscopy (STXM), a newly developed synchrotron-based technique that can determine localization and chemical speciation of most elements in nanoscale, was also adopted to detect cellular distribution and speciation of $\mathrm{Cr}$ in both $\mathrm{Cr}(\mathrm{VI})$ treated hyphae and mycorrhizal roots [24].

\section{Materials and methods}

\subsection{Root-organ cultures}

In vitro cultures of AM fungus Rhizophagus irregularis DAOM 197198 with Agrobacterium rhizogenes (Ri T-DNA) transformed car$\operatorname{rot}$ (Daucus carota L.) roots in solid M medium gelled with $0.4 \%(\mathrm{w} / \mathrm{v})$ phytagel was established according to St-Arnaud et al's methods [25]. Detailed methods are described in the Supplementary Information.

\subsection{Cultivation of extraradical mycelium (ERM)}

Two-compartment petri plates with $9 \mathrm{~cm}$ diameter (Fig. S1) were used, similar to our previous study [21]. The detailed methods for ERM cultivation are described in the Supplementary Information.

\section{3. $\operatorname{Cr}(V I)$ treatments}

For $\mathrm{Cr}(\mathrm{VI})$ treatment, liquid $\mathrm{M}$ medium with $0,0.05,0.1,0.2$, $1.0 \mathrm{mmol} \mathrm{L}^{-1} \mathrm{Cr}(\mathrm{VI})$ (in the form of $\mathrm{K}_{2} \mathrm{CrO}_{4}$ ) but without sucrose, vitamins, potassium iodide, EDTA-Fe and phosphate were used [21]. There was no reduction of $\mathrm{Cr}(\mathrm{VI})$ to $\mathrm{Cr}(\mathrm{III})$ after addition of $\mathrm{Cr}(\mathrm{VI})$ to this modified liquid $\mathrm{M}$ medium for $96 \mathrm{~h}$ (Fig. S2). The modified $\mathrm{M}$ medium with different concentrations of $\mathrm{Cr}(\mathrm{VI})$ was added to the $\mathrm{HC}$ when the old medium was removed with a pipette and the mycelium was washed carefully with Milli-Q water. Here, $0 \mathrm{mmol} \mathrm{L}^{-1} \mathrm{Cr}(\mathrm{VI})$ treatment was considered as control treatment. Each $\mathrm{Cr}(\mathrm{VI})$ treatment had 9 replicates, which were collected after $\mathrm{Cr}(\mathrm{VI})$ exposure for $24 \mathrm{~h}, 48 \mathrm{~h}$ and $96 \mathrm{~h}$ ( 3 replicates were collected at each time), respectively. In addition, 3 cultures with both ERM and mycorrhizal roots developed in HC (Fig. S1b) and treated with $1.0 \mathrm{mmol} \mathrm{L}^{-1} \mathrm{Cr}(\mathrm{VI})$ for $96 \mathrm{~h}$ were arranged to detect the cellular distribution and speciation of $\mathrm{Cr}$ in mycorrhizal roots exposed to $\mathrm{Cr}(\mathrm{VI})$.

\subsection{Assessment of variables}

At harvest, spore number in RC and HC was assessed by using 1$\mathrm{cm}$ grids marked on the bottom of each petri plate [26]. The roots in 
RC were collected from the medium by solubilizing the solidified M media with 10 vols of citrate buffer ( $\mathrm{pH} 6.0$ ), and then washed carefully with Milli-Q water and weighed. ERM in $\mathrm{HC}$ was weighed after being washed thoroughly with cold $0.5 \mathrm{mM} \mathrm{Ca}\left(\mathrm{NO}_{3}\right)_{2}\left(4^{\circ} \mathrm{C}\right)$ and Milli-Q water to remove apoplastic $\mathrm{Cr}$. A subsample of fresh ERM was collected for phosphatase activity measurement, FE-SEM-EDS and STXM analysis, while the remaining ERM was frozen in liquid nitrogen and then lyophilized in a freeze dryer at $-50^{\circ} \mathrm{C}$ for $48 \mathrm{~h}$. The dried ERM samples were motor-homogenized in liquid nitrogen for XAFS analysis $[27,28]$. In addition, fresh mycorrhizal roots in $\mathrm{HC}$ treated with $1.0 \mathrm{mmol} \mathrm{L}^{-1} \mathrm{Cr}(\mathrm{VI})$ for $96 \mathrm{~h}$ were also collected for XAFS (the sample preparation method is the same to ERM) and STXM analysis.

For evaluation of AM colonization, sub-samples of fresh roots were cut into $1 \mathrm{~cm}$ fragments, cleared in $10 \% \mathrm{KOH}$ at $90^{\circ} \mathrm{C}$ for $1 \mathrm{~h}$, rinsed in $5 \% \mathrm{HCl}$ for $5 \mathrm{~min}$, and stained with $0.05 \%$ Trypan blue at $90^{\circ} \mathrm{C}$ for $10 \mathrm{~min}$ following a modification of the methods of Phillips and Hayman [29], in which phenol was omitted from solutions. The intensity of mycorrhizal colonization in the whole root system (M\%) was assessed by the method of Trouvelot et al. [30] by using MYCOCALC software.

Alkaline phosphatase (ALP) and acid phosphatase (ACP) activities in hyphae were measured by a fluorescence-based method according to van Aarle et al. [31]. Detailed methods are described in the Supplementary Information. The ALP and ACP activity was assessed using the magnified intercepts method described by McGonigle et al. [32] and expressed as percentage of total intercepts (200 hyphal intersections were assessed).

\subsection{FE-SEM-EDS analysis}

Hyphal samples from all 3 replicates of each treatment were mixed for SEM-EDS analysis. Fresh hyphae were fixed with $2.5 \%$ glutaraldehyde in $50 \mathrm{mM}$ piperazine-1,4-bisethanesulfonic acid (PIPES) buffer solution ( $\mathrm{pH} \mathrm{7.2)} \mathrm{at} 4{ }^{\circ} \mathrm{C}$ overnight and thoroughly washed with the same buffer solution, followed by fixation with $1 \%$ osmium tetroxide for $2 \mathrm{~h}$, and then dehydrated by a series of acetone solutions $(30 \%, 50 \%, 70 \%, 80 \%, 90 \%, 100 \%$ ) [33]. After that, the hyphae were mounted onto conductive graphite stubs, air-dried, sputter-coated and analyzed using FE-SEM-EDS (SU-8020, Hitachi, Japan). EDS analysis was taken at different positions of the fungal samples. The electron beam acceleration tension was fixed to $15.0 \mathrm{KV}$, the takeoff angle was $35.0^{\circ}$, and the acquisition time for the spectrum was $20 \mathrm{~s}$. In order to compare element concentrations among different positions, each position area for EDS analysis was set to approximately $0.25 \mu \mathrm{m} \times 0.25 \mu \mathrm{m}$.

\subsection{STXM analysis}

Extraradical mycelium and mycorrhizal roots treated with $1.0 \mathrm{mmol} \mathrm{L}^{-1} \mathrm{Cr}(\mathrm{VI})$ were used for STXM study. Fresh hyphae were rinsed with Milli-Q water and adhered to $\mathrm{Cu}$ grids and allowed to dry at room temperature under anoxic conditions [34]. Fresh mycorrhizal roots were fixed and dehydrated, and then embedded in Spurr's resin, cut into $1.4 \mu \mathrm{m}$ sections by a Leica Ultracut UCT (Leica, Germany) with a glass knife, which were then collected on Cu grids and air-dried [35].

The $\mathrm{Cu}$ grids attached with dried hyphae or root sections were brought to the BL08U1A beamline at the Shanghai Synchrotron Radiation Facility (SSRF, Shanghai, China), adhered to the sample holders and then loaded into the experimental chamber for STXM analysis. A dual-energy ratio contrast analysis was conducted to investigate the spatial distribution of different $\mathrm{Cr}$ species in the chosen regions of the samples [36]. The detailed STXM analytic methods are described in the Supplementary information. In order to observe fungal structures in cutting sections of mycorrhizal roots

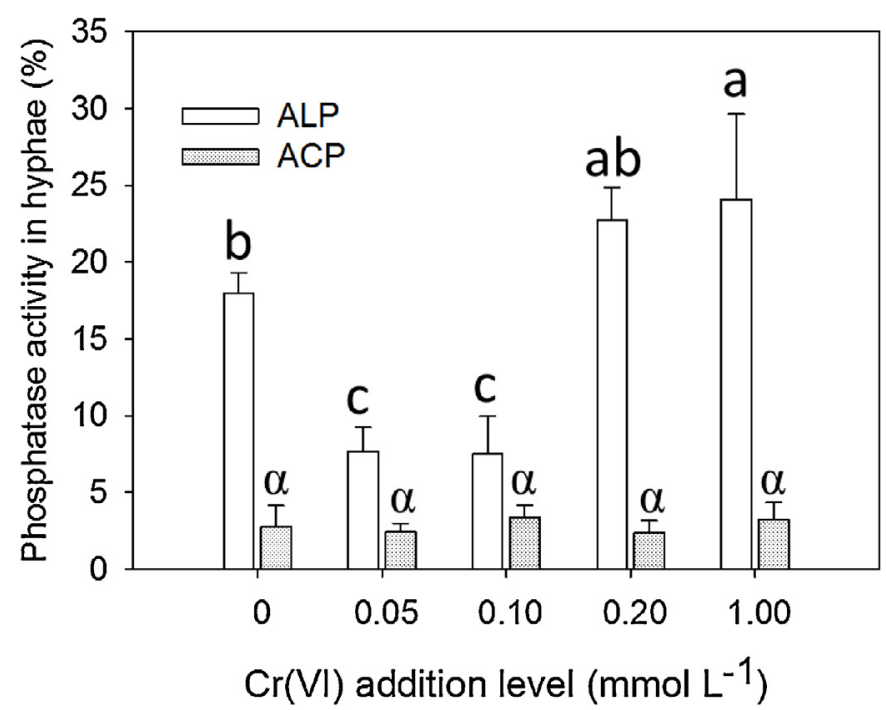

Fig. 1. Proportion of alkaline phosphatase (ALP) activity and acid phosphatase (ACP) activity in the extraradical hyphae treated with different $\mathrm{Cr}(\mathrm{VI})$ levels for $96 \mathrm{~h}$. Different letters above the columns indicate significant differences (Duncan test, $P<0.05$ ) between different treatments. The error bars represent $\operatorname{SD}(n=3)$.

under a light microscope (DP25, Olympus, Japan), root sections were stained with Toluidine blue $\mathrm{O}(0.05 \%$ in $1 \%$ sodium borate in $\mathrm{H}_{2} \mathrm{O}$ ) after STXM analysis [15].

\subsection{XAFS analysis}

The lyophilized and homogenized ERM and root samples were attached uniformly to kapton ${ }^{\circledR}$ tape (Lanmar Inc., Northbrook, IL, USA). The XAFS spectra of the ERM samples were collected on beamline 1W1B at the Beijing Synchrotron Radiation Facility (BSRF). Detailed methods are described in the Supplementary Information. The XAFS spectra were analyzed with the program ATHENA and ARTEMIS of the software package DEMETER (or IFEFFIT) [37].

\subsection{Statistical analysis}

Means of spore numbers, root and hyphal biomass, root M\%, phosphatase activity (including ALP and ACP activity) in ERM, and the means of $\mathrm{P}$ and $\mathrm{Cr}$ concentrations (including at.\% and $\mathrm{wt} \%$ ) in different parts of hyphae and spores determined by EDS, were compared by Duncan's multiple range test by using the SPSS statistical package (SPSS Statistics, Ver 18, IBM, Armonk, New York, USA). Pearson's correlations coefficient between $\mathrm{P}$ and $\mathrm{Cr}$ concentration was analyzed using the SPSS statistical package.

\section{Results and discussions}

\subsection{Mycorrhizal development and hyphal phosphatase activity}

The spore number reached approximately 2000 in both RC and HC after cultivation for nearly 3 months (Table S1), and the fresh weight of the extraradical mycelium (ERM) in HC varied from 13.3 to $20.5 \mathrm{mg}$ with no significant difference among different treatments. Root fresh weights were between 373 and $432 \mathrm{mg}$ in RC, with the intensity of mycorrhizal colonization in the whole root system (M\%) above $40 \%$ for all treatments (Table S1). The results indicated that although the hyphae in $\mathrm{HC}$ was exposed to $\mathrm{Cr}(\mathrm{VI})$, the AM symbiosis in RC still developed well. The ALP and ACP activities of ERM were shown in Figs. S3, S4 and 1 . In general, a higher percentage of ERM structures showed ALP activity than ACP activity. $18.0 \%$ of ERM structures showed ALP activity in control treatment, 


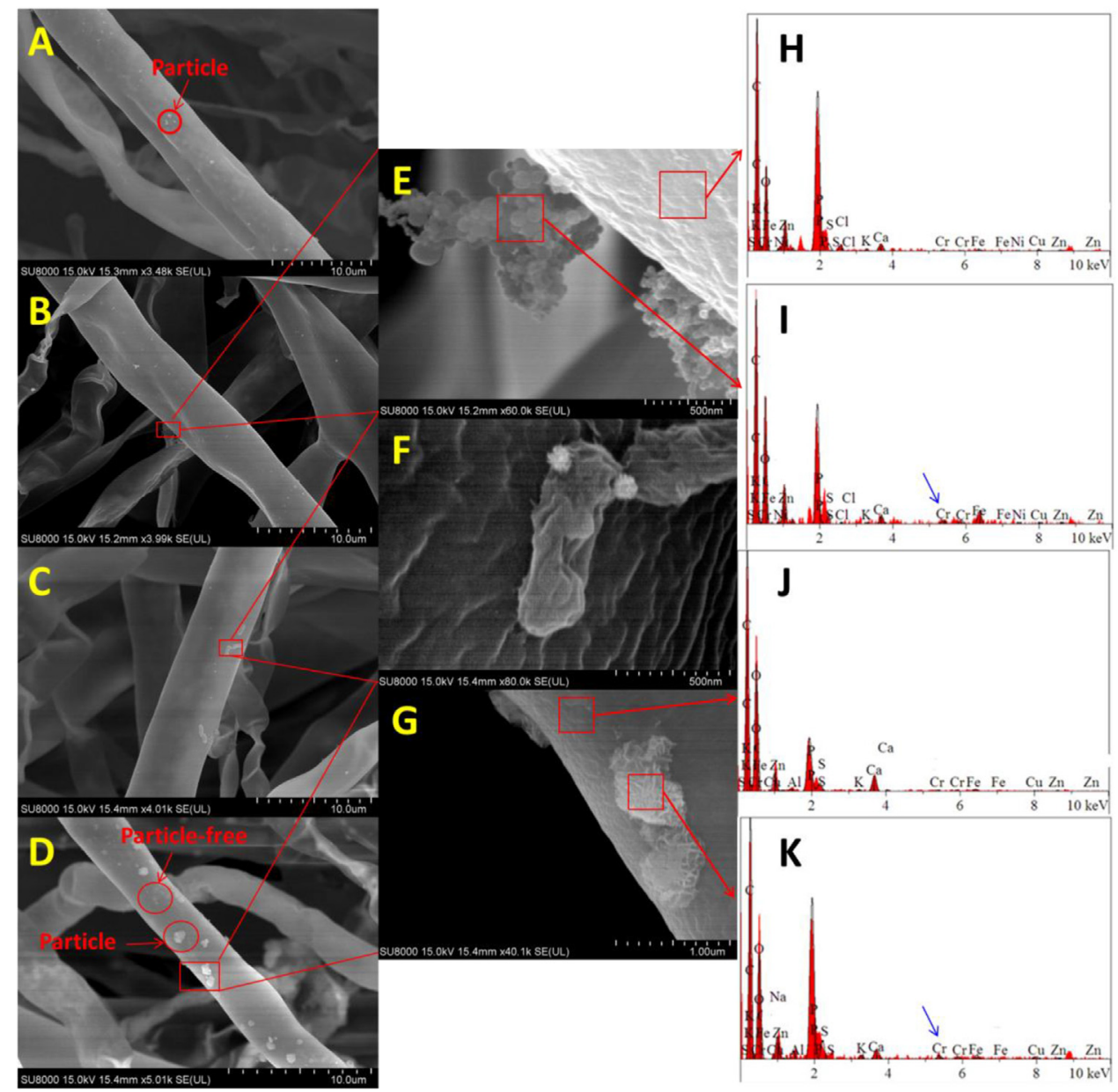

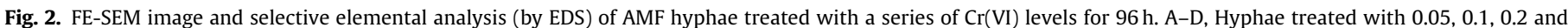

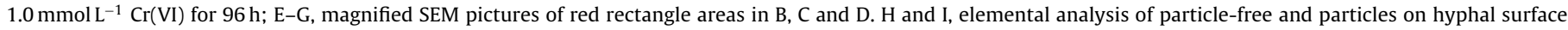

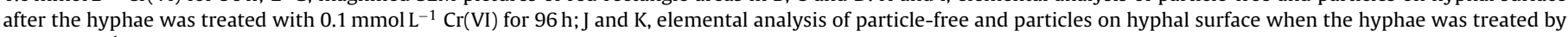

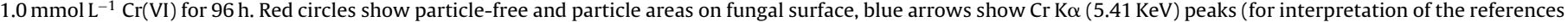
to colour in this figure legend, the reader is referred to the web version of this article).

and then the percentage decreased to $7.69 \%$ and $7.51 \%(P<0.05)$ when ERM was treated with 0.05 and $0.1 \mathrm{mmol} \mathrm{L}^{-1} \mathrm{Cr}(\mathrm{VI})$ for $96 \mathrm{~h}$, but increased to $22.7 \%$ and $24.1 \%(P<0.05)$ when the $\mathrm{Cr}(\mathrm{VI})$ concentration increased to 0.2 and $1.0 \mathrm{mmol} \mathrm{L}^{-1}$ (Fig. 1). However, only $2.4 \%$ to $3.4 \%$ of ERM structures show ACP activity in all treatments. As ALP activity can serve as a marker for AMF metabolic activity [38], the present results may indicate that AMF can maintain some metabolic activities under $\mathrm{Cr}(\mathrm{VI})$ contaminations. Besides, when the hyphae was treated with $0,0.05,0.1,0.2,1.0 \mathrm{mmol} \mathrm{L}^{-1} \mathrm{Cr}(\mathrm{VI})$ for $96 \mathrm{~h}$, the $\mathrm{pH}$ in the hyphal compartment increased to $6.5,6.4,6.2$, $6.5,6.1$ respectively without significant differences between each other. The increased $\mathrm{pH}$ may result from active uptake of $\mathrm{NO}^{3-}-\mathrm{N}$ by the AM fungus, which was consistent with our previous study [21].

\subsection{Morphological and phosphorus concentration changes in AMF exposed to $\mathrm{Cr}(\mathrm{VI})$}

For the control treatment, the surface of both hyphae and spores was nearly smooth (Fig. S5). However, when exposed to $\mathrm{Cr}(\mathrm{VI})$, AMF surface turned rougher and formed large quantities of particles (Fig. 2, Figs. S6 and S7). These particles tended to get bigger with time and the elevating level of $\mathrm{Cr}(\mathrm{VI})$ exposure (Fig. 2), e.g. the diameter of the particles on the surface of hyphae exposed to $1.0 \mathrm{mmol} \mathrm{L}^{-1} \mathrm{Cr}(\mathrm{VI})$ exceeded $1 \mu \mathrm{m}$ (Fig. 2D), and was much bigger than that on the hyphae exposed to $0.05 \mathrm{mmol} \mathrm{L}^{-1} \mathrm{Cr}(\mathrm{VI})$ (Fig. 2A). These particles exhibited strong $\mathrm{C}, \mathrm{O}$ and $\mathrm{P}$ signals by EDS analysis (Fig. 2I \& K, Fig. S7G), which suggests that they are probably organic exudates of the fungi, which are generally called extracellular polymeric substances (EPS) [39]. It was interesting to find that these particles also contained certain amounts of Fe (with wt\% values of $0.9-4.2 \%$ ), indicating that they probably include glomalin-related soil protein (GRSP), which is an insoluble glycoprotein produced by AMF that contains tightly bound Fe $(0.04-8.8 \%)$ [40]. Besides, GRSP also consists of oligosaccharides, amino acids, carbohydrates, and other organic compounds [40], which usually play an important role in sequestering heavy metals [41,42]. However, we are still not definitely sure whether the particles here are EPS, and whether they contain GRSP. In order to investigate the interaction of those particles with $\mathrm{Cr}$, we further distinguished the fungal surface into two parts: particle and particle-free parts (Fig. 2D).

Besides the morphological changes, another important change is $\mathrm{P}$ concentration in AMF. In the control treatments (no $\mathrm{Cr}$ contamination), EDS analysis revealed a stronger $P$ signal in spores than in hyphae (Fig. S5B, C, E and F). This may result from different composition of spores and hyphae $[43,44]$. However, when exposed to $\mathrm{Cr}(\mathrm{VI})$, the P signal in hyphae increased markedly (Fig. 2H-K). This can also be confirmed by the fact that $P$ concentrations (represented as at.\% and wt\% values by EDS) in both particle and particle-free hyphae exposed to $\mathrm{Cr}(\mathrm{VI})$ were much higher than that of control 


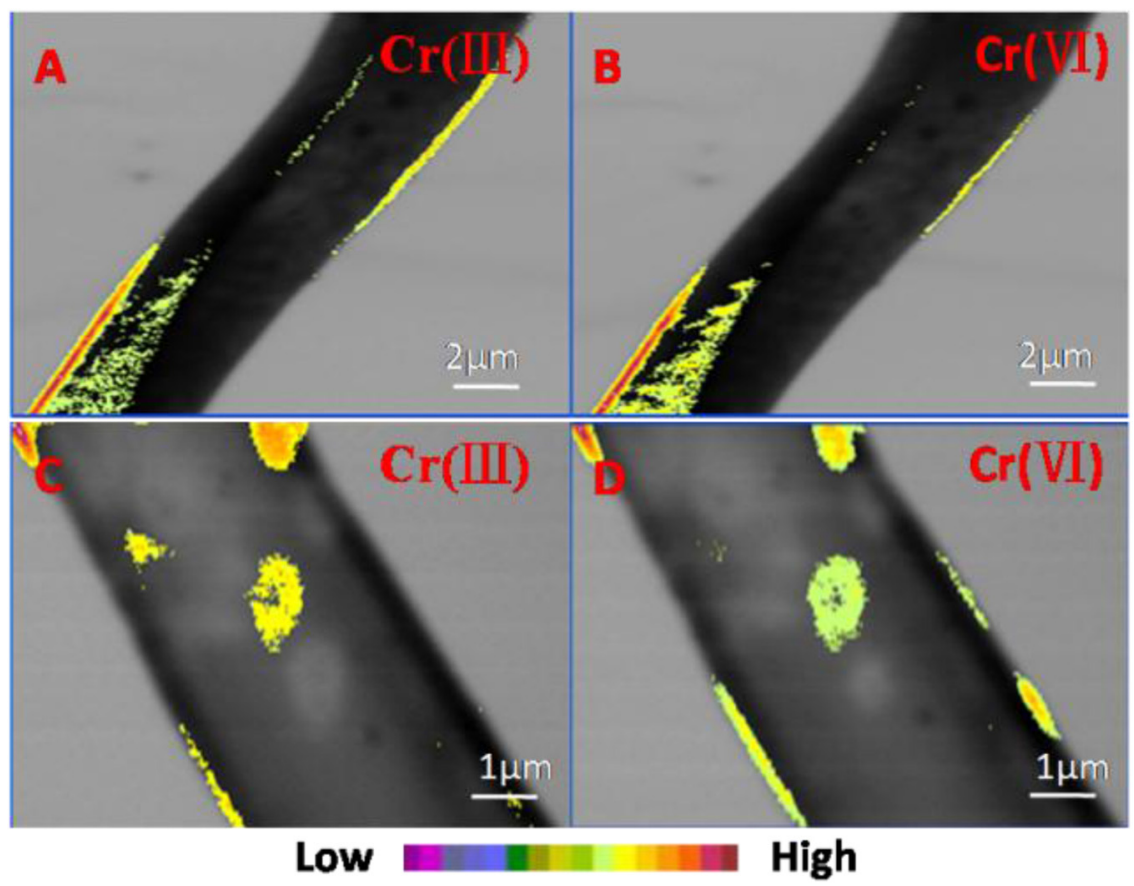

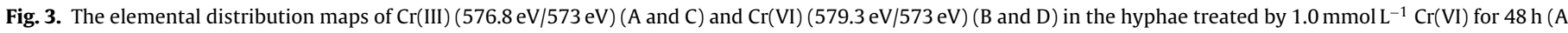
and $\mathrm{B}$ ) and $96 \mathrm{~h}$ ( $\mathrm{C}$ and $\mathrm{D})$ determined by a dual-energy ratio contrast analysis based on scanning transmission soft X-ray microscopy (STXM).

hyphae $(P<0.05)$ (Table 1$)$. This suggests that AM hyphae can accumulate more $\mathrm{P}$ under $\mathrm{Cr}(\mathrm{VI})$ stress. However, this trend did not occur in spores as both $\mathrm{Cr}(\mathrm{VI})$ treated and control spores held similar P concentrations (more than 10 wt\% by EDS) (Fig. S5E \& F, Fig. S7G \& H), which maybe relate with the development stage of the spores or the $\mathrm{Cr}(\mathrm{VI})$ exposure time.

\subsection{Distribution and speciation of $\mathrm{Cr}$ in the extraradical mycelium (ERM)}

In control treatment, there was no $\mathrm{Cr}$ signal in different parts of both hyphae and spores (Fig. S5). However, when exposed to $\mathrm{Cr}(\mathrm{VI}), \mathrm{Cr}$ was almost exclusively detected in those particles on the surface of hyphae and spores (Figs. 2 and S7). It seems that most of $\mathrm{Cr}$ were mainly located in those EPS like particles on fungal surface and not absorbed by the fungi, which is consistent with our previous results showing only a small part of $\mathrm{Cr}$ was absorbed by AMF and transported to plant roots [21]. To prove this, we compared the at.\% and wt\% values of $\mathrm{Cr}$ in particles and particle-free areas of hyphae treated with different $\mathrm{Cr}(\mathrm{VI})$ levels. Nearly all par- ticles on hyphal surface held higher $\mathrm{Cr}$ wt\% values (or $\mathrm{Cr}$ at.\% values) than the particle-free parts did irrespective of $\mathrm{Cr}(\mathrm{VI})$ addition levels (Table 1) $(P<0.05)$, which showed that $\mathrm{Cr}$ was mainly accumulated in those particles on hyphal surface. Similar with mycelium, $\mathrm{Cr}$ also mainly aggregated in particles on spore surface (Fig. S7). For example, the at.\% and wt\% values of $\mathrm{Cr}$ were $0.48 \%$ and $1.39 \%$ in particles on the surface of spores exposed to $0.2 \mathrm{mmol} \mathrm{L}^{-1} \mathrm{Cr}(\mathrm{VI})$, which were significantly higher than that in particle-free parts of spores (at.\% and wt\% values of $\mathrm{Cr}$ were $0.19 \%$ and $0.63 \%$ ) (independent $t$-test, $P<0.05, \mathrm{n}=4$ ). The heavy metal sequestration by surface exudates like EPS has been reported to be a key process relieving metal toxicity to microorganisms $[45,46]$. EPS generally contains numerous functional groups, such as carboxyl, phosphoric, amine, and hydroxyl groups, which can adsorb metals via ion exchange, complexation, surface precipitation etc. [45,47], or alter metal speciation [e.g. reduction of $\mathrm{Cr}(\mathrm{VI})$ to $\mathrm{Cr}(\mathrm{III})]$, and thus reduce toxic metal bioavailability. Similar with ectomycorrhizal fungi [39], the present finding revealed that AM fungi could possibly produce EPS like substances to immobilize $\mathrm{Cr}$ and reduce $\mathrm{Cr}$ uptake. This finding is also possibly in accordance with results obtained by Gil-Cardeza

Table 1

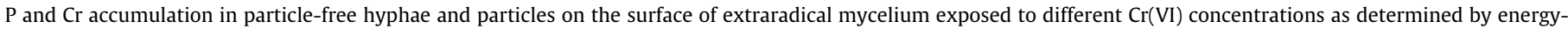
dispersive X-ray spectroscopy (EDS).Values are mean $\pm \operatorname{SD}(n=4)$. Means followed with the same letter are not significantly different (Duncan test, $P<0.05)$.

\begin{tabular}{|c|c|c|c|c|c|}
\hline \multirow{2}{*}{$\begin{array}{l}\mathrm{Cr}(\mathrm{VI}) \\
\text { concentration }\end{array}$} & \multirow[t]{2}{*}{ Site } & \multicolumn{2}{|l|}{$\mathrm{P}$} & \multicolumn{2}{|l|}{$\mathrm{Cr}$} \\
\hline & & at.\% ${ }^{\mathrm{b}}$ & wt $\%^{c}$ & at.\% & wt $\%$ \\
\hline $0 \mathrm{mmol} \mathrm{L}^{-1}$ & Whole & $0.48 \pm 0.23 \mathrm{~d}$ & $1.07 \pm 0.51 \mathrm{ef}$ & $0.09 \pm 0.02 \mathrm{~d}$ & $0.34 \pm 0.09 d$ \\
\hline \multirow{2}{*}{$0.05 \mathrm{mmol} \mathrm{L}^{-1}$} & Particle $^{\mathrm{a}}$-free & $5.12 \pm 0.76 a b c$ & $10.48 \pm 1.44 a b c$ & $0.08 \pm 0.02 \mathrm{~d}$ & $0.27 \pm 0.07 d$ \\
\hline & Particle & $2.70 \pm 1.92 \mathrm{~cd}$ & $5.11 \pm 3.82 \mathrm{de}$ & $0.47 \pm 0.17 a$ & $1.43 \pm 0.47 a$ \\
\hline \multirow[t]{2}{*}{$0.1 \mathrm{mmol} \mathrm{L}^{-1}$} & Particle-free & $5.89 \pm 1.16 \mathrm{ab}$ & $11.90 \pm 1.99 \mathrm{abc}$ & $0.15 \pm 0.06 \mathrm{~cd}$ & $0.51 \pm 0.17 \mathrm{~cd}$ \\
\hline & Particle & $4.02 \pm 1.11 b c$ & $7.84 \pm 2.20 \mathrm{bcd}$ & $0.34 \pm 0.11 \mathrm{ab}$ & $1.09 \pm 0.34 \mathrm{ab}$ \\
\hline \multirow[t]{2}{*}{$0.2 \mathrm{mmol} \mathrm{L}^{-1}$} & Particle-free & $3.95 \pm 1.34 b c$ & $8.17 \pm 2.73 b c d$ & $0.12 \pm 0.04 d$ & $0.43 \pm 0.14 d$ \\
\hline & Particle & $6.49 \pm 1.38 \mathrm{ab}$ & $11.99 \pm 2.48 \mathrm{ab}$ & $0.36 \pm 0.15 a b$ & $1.11 \pm 0.42 \mathrm{ab}$ \\
\hline \multirow[t]{2}{*}{$1.0 \mathrm{mmol} \mathrm{L}^{-1}$} & Particle-free & $3.90 \pm 1.89 b c$ & $7.74 \pm 3.31 \mathrm{~cd}$ & $0.15 \pm 0.04 \mathrm{~cd}$ & $0.46 \pm 0.10 \mathrm{~cd}$ \\
\hline & Particle & $7.12 \pm 2.33 a$ & $12.73 \pm 2.95 a$ & $0.28 \pm 0.08 b$ & $0.86 \pm 0.21 b$ \\
\hline
\end{tabular}

\footnotetext{
a "Particle", produced by AMF upon $\mathrm{Cr}(\mathrm{VI})$ exposure, possibly is extracellular polymeric substances.

b "at.\%", atom percentage content.

c “wt\%”, weight percentage content.
} 


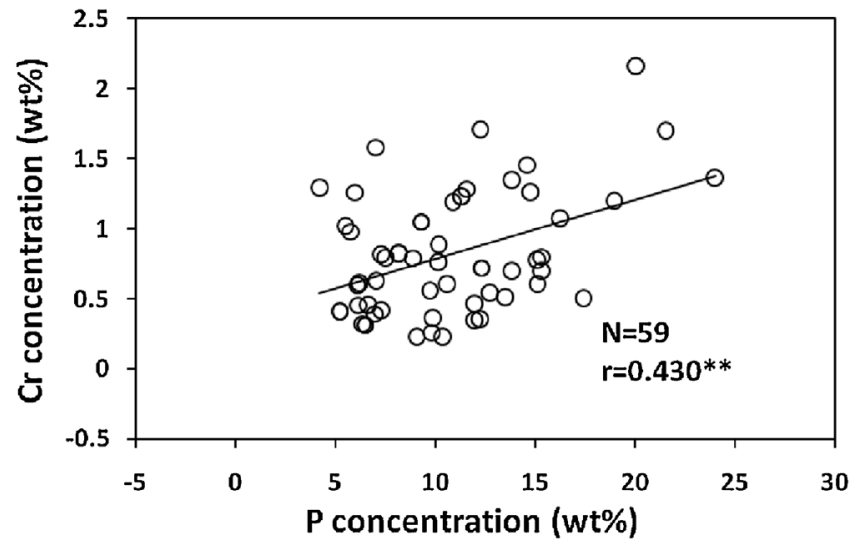

Fig. 4. Pearson's correlation between chromium $(\mathrm{Cr})$ and phosphorus $(\mathrm{P})$ concentrations by energy dispersive X-ray fluorescence of SEM among hyphae and spores exposed to a series of $\mathrm{Cr}(\mathrm{VI})$ levels. $\mathrm{r}$, Pearson's correlation coefficient; ${ }^{* *}, P<0.01$.

et al. [42], who suggest that $\mathrm{Cr}$ (III) is bound to GRSP (probably a key compounds of exudates produced by AMF) in soil contaminated with Cr.

The synchrotron based STXM analysis further corroborated the SEM-EDS results, showing that $\mathrm{Cr}$ mainly aggregated on hyphal surface, especially in those particles when the hyphae are exposed to $1.0 \mathrm{mmol} \mathrm{L}^{-1} \mathrm{Cr}(\mathrm{VI})$ for $96 \mathrm{~h}$ (Fig. 3). Although the hyphal samples for SEM-EDS analysis had been chemical fixed, the SEM-EDS results for $\mathrm{Cr}$ distribution pattern on fungal surface was consistent with STXM analysis where the hyphal samples were not chemical fixed. This may at least partially indicates that chemical fixation may not cause $\mathrm{Cr}$ relocalization in AMF in the present experimental situation.

In addition, the results of STXM study also revealed that amounts of $\mathrm{Cr}(\mathrm{VI})$ was reduced to $\mathrm{Cr}(\mathrm{III})$, and the similar spatial distribution of these two $\mathrm{Cr}$ species further indicated that $\mathrm{Cr}(\mathrm{VI})$ reduction probably occurred on fungal surface (especially in those particles) (Fig. 3). Just as Park et al. [48] mentioned, $\mathrm{Cr}$ immobilization on fungal surface was probably an "adsorption coupled reduction" process. $\mathrm{Cr}(\mathrm{VI})$ was first bound to the positively charged complexing groups on fungal surfaces, and then reduced to $\mathrm{Cr}$ (III) by adjacent electron-donor compounds (such as glutathione, cysteine, amino acid etc.), or by chromate reductase excreted by the fungi [49-51]. In addition, it is essential to point out that a small proportion of $\mathrm{Cr}$ might also be absorbed by AMF as our previous study has confirmed the direct uptake and transport of Cr by ERM [20,21]. However, we can hardly detect those $\mathrm{Cr}$ in the fungi using STXM analysis as the amount is much lower compared with the $\mathrm{Cr}$ precipitating on the fungal surface.

However, we still don't know the exact $\mathrm{Cr}$ speciation on fungal surface, which is of importance for understanding the mechanisms underlying $\mathrm{Cr}$ immobilization. It is well known that phosphate groups are negatively charged groups that can easily precipitate $\mathrm{Cr}(\mathrm{III})$, and AM fungi are well known for improving plant $\mathrm{P}$ acquisition [52]. Large amounts of polyphosphates (polyP) have been observed in AMF hyphae [53]. Besides, more AMF structures showed ALP activity when the fungi are exposed to high levels of $\mathrm{Cr}(\mathrm{VI})$ [above $0.2 \mathrm{mmol} \mathrm{L}^{-1} \mathrm{Cr}(\mathrm{VI})$ ] compared with AMF exposed to no or lower $\mathrm{Cr}(\mathrm{VI})$ concentrations (Fig. 1). As ALP was probably responsible for hydrolysis of pyrophosphate compounds [54], more inorganic phosphate that can complex $\mathrm{Cr}$ might be released in AMF when exposed to $\mathrm{Cr}(\mathrm{VI})$. In fact, our recent work has suggested that AMF can reduce $\mathrm{Cr}(\mathrm{VI})$ to mainly $\mathrm{Cr}(\mathrm{III})$-phosphate analogues at a low $\mathrm{Cr}(\mathrm{VI})$ exposure level [21]. In the present study, we also found high $\mathrm{P}$ signal on AM fungal surface under $\mathrm{Cr}(\mathrm{VI})$ contamination by EDS analysis (Table 1, Fig. 2), which showed a significantly positive correlation with $\mathrm{Cr}$ signals (Fig. 4) (Pearson's correlation coefficient $r=0.430, P<0.01$ ). Therefore, it is reasonable to predict that $\mathrm{Cr}$ is mainly precipitated by phosphate groups (or analogues) on fungal surface.

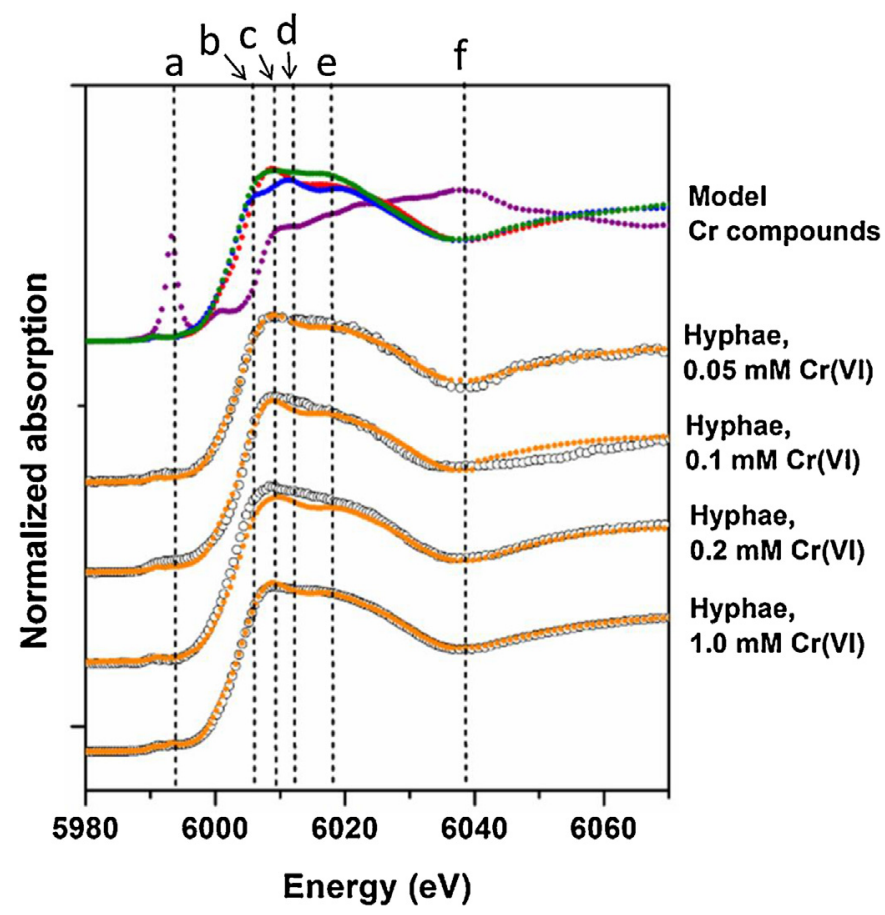

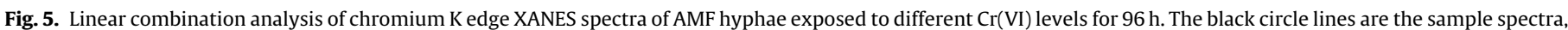

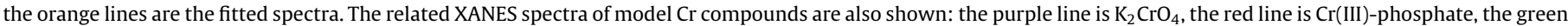

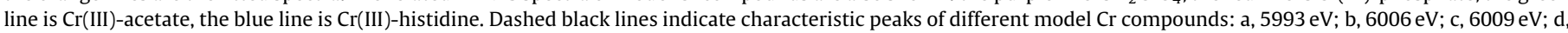
$6012 \mathrm{eV} ; \mathrm{e}, 6018 \mathrm{eV} ; \mathrm{f}, 6039 \mathrm{eV}$ (for interpretation of the references to colour in this figure legend, the reader is referred to the web version of this article). 


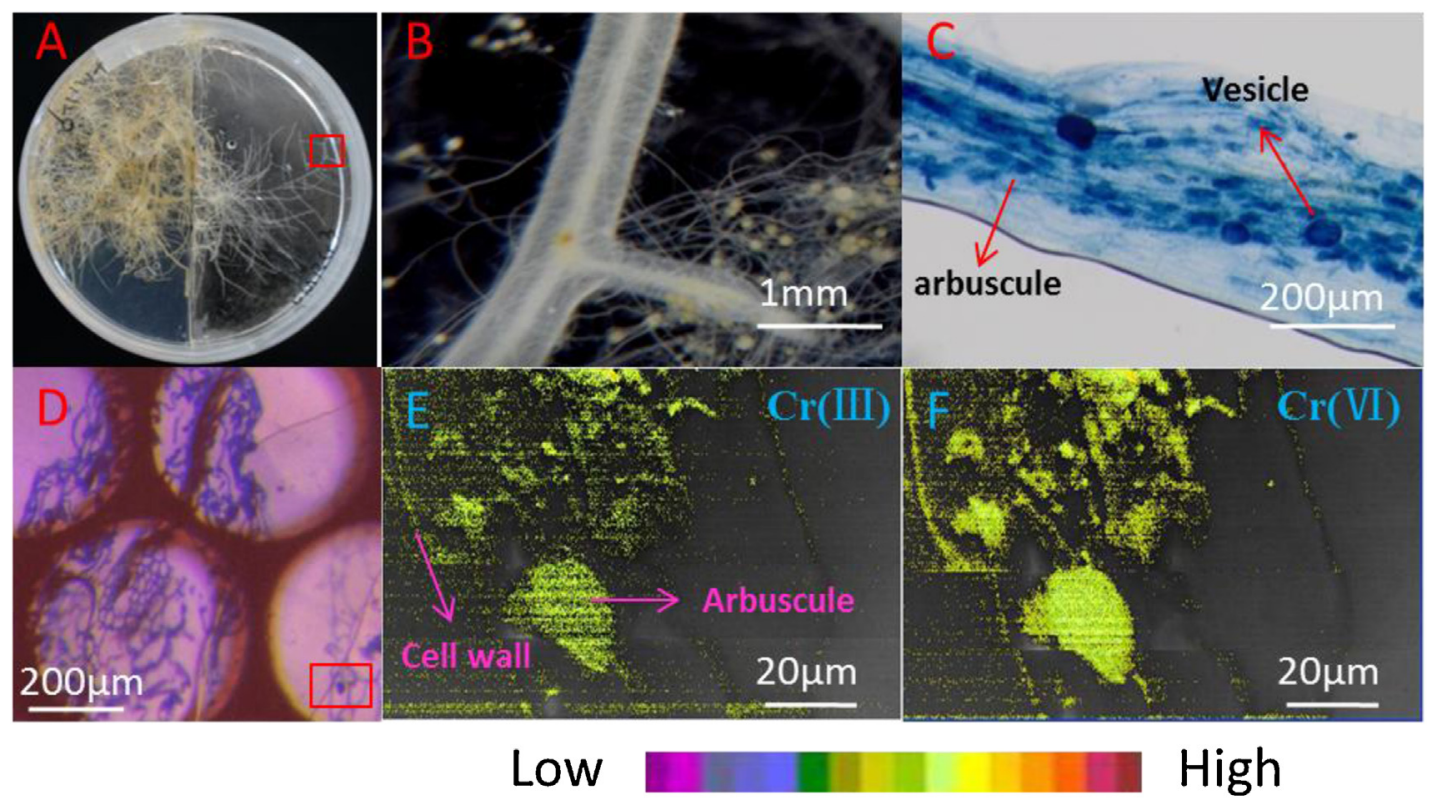

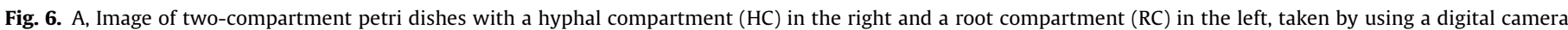

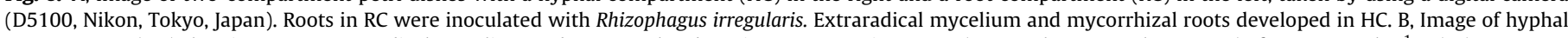

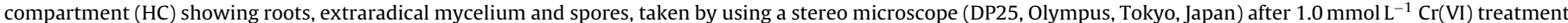

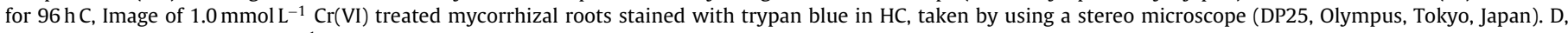

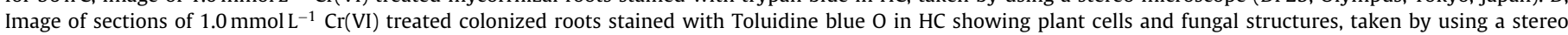

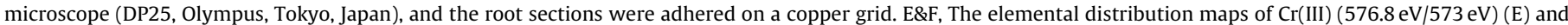

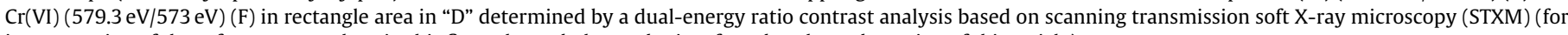
interpretation of the references to colour in this figure legend, the reader is referred to the web version of this article).

\subsection{Cr speciation in ERM - XAFS analysis}

In order to further unravel the $\mathrm{Cr}$ speciation in AMF hyphae, XAFS analysis was conducted. Fig. S8 showed XANES spectra of standard $\mathrm{Cr}$ compounds and hyphal samples treated with different levels of $\mathrm{Cr}(\mathrm{VI})$. Almost all $\mathrm{Cr}$ in AMF was in the form of $\mathrm{Cr}(\mathrm{III})$, as there were nearly no peaks at $5993 \mathrm{eV}$ (the pre-edge peak for XANES spectrum of $\mathrm{Cr}(\mathrm{VI})$ [55]) for nearly all hyphal samples. In addition, the white line of both $\mathrm{Cr}(\mathrm{III})$-phosphate and $\mathrm{Cr}$ (III)acetate at about $6009 \mathrm{eV}$ was also present in nearly all hyphae spectra (Fig. 5). In order to further investigate possible ligands that complex with $\mathrm{Cr}$, we did linear combination analysis of $\mathrm{Cr} \mathrm{K}$ edge XANES spectra (LC-XANES). According to our previous study [21], we chose $\mathrm{K}_{2} \mathrm{CrO}_{4}, \mathrm{Cr}(\mathrm{III})$-phosphate, $\mathrm{Cr}(\mathrm{III})$-cysteine, $\mathrm{Cr}(\mathrm{III})$ histidine and $\mathrm{Cr}$ (III)-acetate for the LC-XANES analysis. The results showed that $\mathrm{Cr}(\mathrm{III})$-phosphate analogues were the main $\mathrm{Cr}$ species (>60\%) in bulk ERM samples exposed to $\mathrm{Cr}(\mathrm{VI})$ (Fig. 5, Table S2), followed by $\mathrm{Cr}(\mathrm{III})$-histidine or $\mathrm{Cr}(\mathrm{III})$-acetate. In addition, there also existed a small fraction of $\mathrm{K}_{2} \mathrm{CrO}_{4}(4.2 \%)$ in ERM treated with the highest $\mathrm{Cr}(\mathrm{VI})$ level, which partially corroborated with the results of STXM analysis showing that a little propotion of $\mathrm{Cr}(\mathrm{VI})$ still exists on the fungal surface.

However, it is essential to point out that the results of XAFS and STXM analysis on $\mathrm{Cr}$ oxidation status are not consistent, as the STXM analysis showed a higher $\mathrm{Cr}(\mathrm{VI})$ signal in hyphae compared with XAFS analysis (Fig. 3, Fig. 5 and Fig. S8). This may result from three reasons: First, STXM analysis was mainly focused on the fungi in situ, while XAFS analysis was for the bulk hyphal sample, as $\mathrm{Cr}$ distribution in fungi is heterogeneous, therefore the results of the two analytic methods may be different; Second, the sample preparation for the STXM and XAFS are different, for XAFS analysis, sample was lyophilized in a freeze dryer and then motorhomogenized in liquid nitrogen $[27,28]$, while for STXM analysis, fresh hyphal samples were air-dried under anoxic conditions [34], $\mathrm{Cr}$ oxidation status may slightly change during sample prepara- tion although we try our best to avoid it, and different processes of sample preparation may result in different $\mathrm{Cr}$ speciation changes; Third, STXM and XAFS may have different capability to distinguish the signal of the two oxidation status of $\mathrm{Cr}$, besides that there may exist photoreduction of $\mathrm{Cr}(\mathrm{VI})$ during STXM or XAFS analysis.

To further confirm $\mathrm{Cr}$ speciation in hyphae, $\mathrm{Cr} \mathrm{K}$ edge EXAFS spectra was analyzed. The results of EXAFS analysis of ERM treated with $1.0 \mathrm{mmol} \mathrm{L}^{-1} \mathrm{Cr}(\mathrm{VI})$ was shown in Fig. S9 and Table S3. The fitting results showed that the hyphae exhibited $5.5 \mathrm{O}$ (or $\mathrm{N}$ ) atoms surrounding $\mathrm{Cr}$ at a distance of $1.98 \AA$, indicating that $\mathrm{Cr}$ is coordinated by $\mathrm{O}$ ( or $\mathrm{N}$ ) atoms. Besides, a weak (but statistically significant) neighbour $\mathrm{Cr}$-P shell was found at $3.07 \AA$ from the central $\mathrm{Cr}$ atom with a coordination number of 1.2 , and $\mathrm{a} \mathrm{Cr}-\mathrm{C}$ bond was also found at $3.26 \AA$ surrounding $\mathrm{Cr}$ with a coordination number of 2.5. This suggests that the $\mathrm{Cr}-\mathrm{O} / \mathrm{N}$ bonds in ERM are probably combined with $\mathrm{Cr}-\mathrm{P}$ or $\mathrm{Cr}-\mathrm{C}$ bonds. Therefore, the XAFS study confirmed the possible complexation of $\mathrm{Cr}$ by phosphate groups, nitrogenous or carboxylic ligands in AMF. Just as FE-SEM-EDS and STXM analysis showed, most of these $\mathrm{Cr}$ compounds may exist in those EPS like particles [produced by AMF upon $\mathrm{Cr}(\mathrm{VI})$ stress] on fungal surface. In addtion, as we meantioned previously [21], a little proportion of $\mathrm{Cr}$ might also be taken up by AMF, and complexed mainly by histidine analogues or carboxylic ligands in the fungi.

\subsection{Cellular imaging and speciation of $\mathrm{Cr}$ in resin sections of mycorrhizal roots}

The STXM analysis of mycorrhizal carrot roots exposed to $1.0 \mathrm{mmol} \mathrm{L}^{-1} \mathrm{Cr}(\mathrm{VI})$ for $96 \mathrm{~h}$ suggested that $\mathrm{Cr}$ was mainly located in cell walls and arbuscules (or intraradical mycelium) in mycorrhizal roots (Fig. 6). This indicates that the fungal structures together with cell walls in mycorrhizal roots could accumulate $\mathrm{Cr}$, and restrain $\mathrm{Cr}$ translocation to plant cytoplasm. The restrain of heavy metals by plant cell walls is a common way plant relieve metal toxicity, which has also been reported in many previous studies [56-59]. The highly 
accumulated $\mathrm{Cr}$ in the intraradical fungal structures may result from $\mathrm{Cr}$ uptake and transport to mycorrhizal roots by the extraradical mycelium $[20,21,60]$, or from $\mathrm{Cr}$ transport to the intraradical fungal structures from plant cells that take up $\mathrm{Cr}$ directly from the environment. Metal compartmentation by intraradical fungal structures was also reported for Cd in previous study [15]. The compartmentation of $\mathrm{Cr}$ by fungal structures could thus reduce $\mathrm{Cr}$ translocation to plant cytoplasm, and relieve $\mathrm{Cr}$ phytotoxicity.

Besides, the STXM also showed that certain amount of $\mathrm{Cr}(\mathrm{VI})$ was reduced to $\mathrm{Cr}$ (III) (Fig. 6E), which indicates a main strategy for mycorrhizal roots to tolerate $\mathrm{Cr}(\mathrm{VI})$. Similar to extraradical mycelium mentioned above, $\mathrm{Cr}(\mathrm{VI})$ was possibly reduced by electron-donor compounds or chromate reductase in both fungal structures or plant cells $[27,51,61]$. Cr(III) is easily bound to phosphate, carboxyl or thiol groups, resulting in lower mobility and toxicity [27].

To further investigate $\mathrm{Cr}$ speciation in mycorrhizal roots exposed to $\mathrm{Cr}(\mathrm{VI})$ stress, XANES analysis was conducted. The results indicated that a mixture of $\mathrm{Cr}(\mathrm{III})$-acetate (48.7\%), $\mathrm{Cr}$ (III)-histidine (32.8\%), $\mathrm{K}_{2} \mathrm{CrO}_{4}$ (11.3\%) and $\mathrm{Cr}(\mathrm{III})$-phosphate (7.2\%) could well reproduce the $\mathrm{Cr}$ K edge XANES spectrum of mycorrhizal roots (Fig. S10). The XANES analysis corroborated with STXM analysis showing certain amount of $\mathrm{Cr}(\mathrm{VI})$ had been reduced to $\mathrm{Cr}(\mathrm{III})$, while a small proportion of $\mathrm{Cr}(\mathrm{VI})$ still existed in the mycorrhizal roots exposed to $1 \mathrm{mmol} \mathrm{L}^{-1} \mathrm{Cr}(\mathrm{VI})$ for $96 \mathrm{~h}$. The XANES analysis also revealed that $\mathrm{Cr}(\mathrm{III})$ is mainly complexed with carboxylic ligands or histidine analogues in mycorrhizal roots, which is in accordance with our recent study [21], indicating possible mechanisms underlying $\mathrm{Cr}$ immobilization in cell walls and intraradical fungal structures in mycorrhizal roots.

\section{Conclusions}

In summary, the present study has for the first time showed the detailed processes and mechanisms of $\mathrm{Cr}$ immobilization by AM symbioses at cellular level: (1) AMF can produce significant amounts of EPS like particles on fungal surface, which can adsorb and reduce $\mathrm{Cr}(\mathrm{VI})$ to possibly $\mathrm{Cr}(\mathrm{III})$-phosphate analogues; (2) intraradical fungal structures (arbuscules, intraradical mycelium etc) and cell walls in mycorrhizal roots can also reduce $\mathrm{Cr}(\mathrm{VI})$ to $\mathrm{Cr}$ (III), and complex $\mathrm{Cr}$ (III) mainly by carboxylic ligands or histidine analogues, and restrain $\mathrm{Cr}$ translocation to plant cytoplasm. The results could undoubtedly lead to a deeper understanding of the direct contribution of AMF to plant $\mathrm{Cr}(\mathrm{VI})$ tolerance. However, the composition and characteristics of these particles on AM fungal surface upon $\mathrm{Cr}(\mathrm{VI})$ stress need further investigation. Besides, future study should also concern the molecular mechanisms underlying $\mathrm{Cr}$ translocation and transformation on the symbiotic interface of AM symbioses.

\section{Acknowledgements}

The work was financially supported by National Natural Science Foundation of China (41471219 and 41371264). Thanks to Huaina Yu, Lijuan Zhang and Yong Wang for their technical support in Shanghai Synchrotron Radiation Facility (SSRF).

\section{Appendix A. Supplementary data}

Supplementary data associated with this article can be found, in the online version, at http://dx.doi.org/10.1016/j.jhazmat.2016.05. 017.

\section{References}

[1] M. Losi, C. Amrhein, W. Frankenberger Jr., Environmental biochemistry of chromium, Rev. Environ. Contam. Toxicol. 136 (1994) 91-121.
[2] M. Mohanty, H.K. Patra, Attenuation of chromium toxicity by bioremediation technology, Rev. Environ. Contam. Toxicol. 210 (2011) 1-34.

[3] A.K. Shanker, C. Cervantes, H. Loza-Tavera, S. Avudainayagam, Chromium toxicity in plants, Environ. Int. 31 (2005) 739-753.

[4] S.E. Smith, D. Read, Mycorrhizal Symbiosis, third ed., Academic Press, San Diego, 2008.

[5] T. Li, G. Lin, X. Zhang, Y.L. Chen, S.B. Zhang, B.D. Chen, Relative importance of an arbuscular mycorrhizal fungus (Rhizophagus intraradices) and root hairs in plant drought tolerance, Mycorrhiza 24 (2014) 1-8.

[6] N. Garg, R. Pandey, Effectiveness of native and exotic arbuscular mycorrhizal fungi on nutrient uptake and ion homeostasis in salt-stressed Cajanus cajan L. (Millsp.) genotypes, Mycorrhiza 25 (2015) 165-180.

[7] L. Campos-Soriano, J. Garcia-Martinez, B. San Segundo, The arbuscular mycorrhizal symbiosis promotes the systemic induction of regulatory defence-related genes in rice leaves and confers resistance to pathogen infection, Mol. Plant Pathol. 13 (2012) 579-592.

[8] S.L. Wu, X. Zhang, B.D. Chen, Effects of arbuscular mycorrhizal fungi on heavy metal translocation and transformation in the soil-plant continuum, Asian J. Ecotoxicol. (in Chinese) 8 (2013) 847-856.

[9] C. Leyval, K. Turnau, K. Haselwandter, Effect of heavy metal pollution on mycorrhizal colonization and function: physiological, ecological and applied aspects, Mycorrhiza 7 (1997) 139-153.

[10] B.D. Chen, Y.G. Zhu, J. Duan, X.Y. Xiao, S.E. Smith, Effects of the arbuscular mycorrhizal fungus Glomus mosseae on growth and metal uptake by four plant species in copper mine tailings, Environ. Pollut. 147 (2007) 374-380.

[11] B.D. Chen, P. Roos, O.K. Borggaard, Y.G. Zhu, I. Jakobsen, Mycorrhiza and root hairs in barley enhance acquisition of phosphorus and uranium from phosphate rock but mycorrhiza decreases root to shoot uranium transfer, New Phytol. 165 (2005) 591-598.

[12] F.T. Davies, J.D. Puryear, R.J. Newton, J.N. Egilla, J.A.S. Grossi, Mycorrhizal fungi enhance accumulation and tolerance of chromium in sunflower (Helianthus annuus), J. Plant Physiol. 158 (2001) 777-786.

[13] J.A. Arias, J.R. Peralta-Videa, J.T. Ellzey, M.N. Viveros, M. Ren, N.S. Mokgalaka-Matlala, H. Castillo-Michel, J.L. Gardea-Torresdey, Plant growth and metal distribution in tissues of Prosopis juliflora-velutina grown on chromium contaminated soil in the presence of Glomus deserticola, Environ. Sci. Technol. 44 (2010) 7272-7279.

[14] S.L. Wu, B.D. Chen, Y.Q. Sun, B.H. Ren, X. Zhang, Y.S. Wang, Chromium resistance of dandelion (Taraxacum platypecidum Diels.) and bermudagrass (Cynodon dactylon [Linn.] Pers.) is enhanced by arbuscular mycorrhiza in $\mathrm{Cr}(\mathrm{VI})$-contaminated soils, Environ. Toxicol. Chem. 33 (2014) 2105-2113.

[15] K. Nayuki, B. Chen, R. Ohtomo, Y. Kuga, Cellular imaging of cadmium in resin sections of arbuscular mycorrhizas using synchrotron micro X-ray fluorescence, Microbes Environ. 29 (2014) 60-66.

[16] N. Ferrol, M. Gonzalez-Guerrero, A. Valderas, K. Benabdellah, C. Azcon-Aguilar, Survival strategies of arbuscular mycorrhizal fungi in Cu-polluted environments, Phytochem. Rev. 8 (2009) 551-559.

[17] E.J. Joner, R. Briones, C. Leyval, Metal-binding capacity of arbuscular mycorrhizal mycelium, Plant Soil 226 (2000) 227-234.

[18] I.M. Weiersbye, C.J. Straker, W.J. Przybylowicz, Micro-PIXE mapping of elemental distribution in arbuscular mycorrhizal roots of the grass Cynodon dactylon, from gold and uranium mine tailings, Nucl. Instrum. Meth. B-Beam Interact. Mater. Atoms 158 (1999) 335-343.

[19] G. Rufyikiri, S. Declerck, Y. Thiry, Comparison of ${ }^{233} \mathrm{U}$ and ${ }^{33} \mathrm{P}$ uptake and translocation by the arbuscular mycorrhizal fungus Glomus intraradices in root organ culture conditions, Mycorrhiza 14 (2003) 203-207.

[20] S.L. Wu, X. Zhang, B.D. Chen, Z.X. Wu, T. Li, Y.J. Hu, Y.Q. Sun, Y.S. Wang, Chromium immobilization by extraradical mycelium of arbuscular mycorrhiza contributes to plant chromium tolerance, Environ. Exp. Bot. 122 (2016) 10-18.

[21] S.L. Wu, X. Zhang, Y.Q. Sun, Z.X. Wu, T. Li, Y.J. Hu, D. Su, J.T. Lv, G. Li, Z.S. Zhang, L.R. Zheng, J. Zhang, B.D. Chen, Transformation and immobilization of chromium by arbuscular mycorrhizal fungi as revealed by SEM-EDS TEM-EDS, and XAFS, Environ. Sci. Technol. 49 (2015) 14036-14047.

[22] M. Gonzalez-Guerrero, K. Benabdellah, N. Ferrol, C. Azcon-Aguilar, Mechanisms underlying heavy metal tolerance in arbuscular mycorrhizas, in: C. Azcon-Aguilar, J.M. Barea, S. Gianinazzi, V. Gianinazzi-Pearson (Eds.), Mycorrhizas - Functional Processes and Ecological Impact, Springer Press, Heidelberg, 2009, pp. 107-122.

[23] J.G. Parsons, M.V. Aldrich, J.L. Gardea-Torresdey, Environmental and biological applications of extended X-ray absorption fine structure (EXAFS) and X-ray absorption near edge structure (XANES) spectroscopies, Appl. Spectrosc. Rev. 37 (2002) 187-222.

[24] S. Behrens, A. Kappler, M. Obst, Linking environmental processes to the in situ functioning of microorganisms by high-resolution secondary ion mass spectrometry (NanoSIMS) and scanning transmission X-ray microscopy (STXM), Environ. Microbiol. 14 (2012) 2851-2869.

[25] M. St-Arnaud, C. Hamel, B. Vimard, M. Caron, J. Fortin, Enhanced hyphal growth and spore production of the arbuscular mycorrhizal fungus Glomus intraradices in an in vitro system in the absence of host roots, Mycol. Res. 100 (1996) 328-332

[26] G. Rufyikiri, Y. Thiry, L. Wang, B. Delvaux, S. Declerck, Uranium uptake and translocation by the arbuscular mycorrhizal fungus Glomus intraradices, under root-organ culture conditions, New Phytol. 156 (2002) 275-281.

[27] M. Aldrich, J. Gardea-Torresdey, J. Peralta-Videa, J. Parsons, Uptake and reduction of $\mathrm{Cr}(\mathrm{VI})$ to $\mathrm{Cr}(\mathrm{III})$ by mesquite (Prosopis spp.): chromate-plant 
interaction in hydroponics and solid media studied using XAS, Environ. Sci. Technol. 37 (2003) 1859-1864.

[28] Y.V. Nancharaiah, C. Dodge, V.P. Venugopalan, S.V. Narasimhan, A.J. Francis, Immobilization of $\mathrm{Cr}(\mathrm{VI})$ and its reduction to $\mathrm{Cr}(\mathrm{III})$ phosphate by granular biofilms comprising a mixture of microbes, Appl. Environ. Microbiol. 76 (2010) 2433-2438.

[29] J.M. Phillips, D.S. Hayman, Improved procedures for clearing roots and staining parasitic and vesicular-arbuscular mycorrhizal fungi for rapid assessment of infection, Trans. Brit. Mycol. Soc. 55 (1970) 158-161.

[30] A. Trouvelot, J.L. Kough, V. Gianinazzi-Pearson, Mesure du taux deycorhization VA d'un systeme radiculaire. Recherche de methods d' estimation ayantune ignification fonctionneue, in: V. Gianinazzi-Pearson, S. Gianinazzi (Eds.), Physiological and Genetical Aspects of Mycorrhizae, INRA Press, Paris, 1986, pp. 217-221.

[31] I.M. van Aarle, T.R. Cavagnaro, S.E. Smith, F.A. Smith, S. Dickson, Metabolic activity of Glomus intraradices in Arum- and Paris-type arbuscular mycorrhizal colonization, New Phytol. 166 (2005) 611-618.

[32] T.P. McGonigle, M.H. Miller, D.G. Evans, G.L. Fairchild, J.A. Swan, A new method which gives an objective measure of colonization of roots by vesicular-arbuscular mycorrhizal fungi, New Phytol. 115 (1990) 495-501.

[33] P.W. Baker, K. Ito, K. Watanabe, Marine prosthecate bacteria involved in the ennoblement of stainless steel, Environ. Microbiol. 5 (2003) 925-932.

[34] J. Miot, K. Benzerara, G. Morin, A. Kappler, S. Bernard, M. Obst, C. Ferard, F. Skouri-Panet, J.-M. Guigner, N. Posth, M. Galvez, G.E. Brown Jr., F. Guyot, Iron biomineralization by anaerobic neutrophilic iron-oxidizing bacteria, Geochim. Cosmochim. Acta 73 (2009) 696-711.

[35] P. Zhang, Y. Ma, Z. Zhang, X. He, J. Zhang, Z. Guo, R. Tai, Y. Zhao, Z. Chai, Biotransformation of ceria nanoparticles in cucumber plants, ACS Nano 6 (2012) 9943-9950.

[36] X. Zhang, Z. Xu, R. Tai, X. Zhen, Y. Wang, Z. Guo, R. Yan, R. Chang, B. Wang, M. Li, Ratio-contrast imaging of dual-energy absorption for element mapping with a scanning transmission X-ray microscope, J. Synchrotron Radiat. 17 (2010) 804-809.

[37] B. Ravel, M. Newville, ATHENA, ARTEMIS, HEPHAESTUS: data analysis for X-ray absorption spectroscopy using IFEFFIT, J. Synchrotron Radiat. 12 (2005) 537-541.

[38] B. Tisserant, V. Gianinazzipearson, S. Gianinazzi, A. Gollotte, In planta histochemical staining of fungal alkaline-phosphatase activity for analysis of efficient arbuscular mycorrhizal infections, Mycol. Res. 97 (1993) 245-250.

[39] S.A. Gazze, L. Saccone, M.M. Smits, A.L. Duran, J.R. Leake, S.A. Banwart, K.V. Ragnarsdottir, T.J. McMaster, Nanoscale observations of extracellular polymeric substances deposition on phyllosilicates by an ectomycorrhizal fungus, Geomicrobiol. J. 30 (2013) 721-730.

[40] K. Nichols, Characterization of glomalina glycoprotein produced by arbuscular mycorrhizal fungi, PhD dissertation, University of Maryland, College Park, Maryland, 2003.

[41] M.C. Gonzalez-Chavez, R. Carrillo-Gonzalez, S.F. Wright, K.A. Nichols, The role of glomalin, a protein produced by arbuscular mycorrhizal fungi, in sequestering potentially toxic elements, Environ. Pollut. 130 (2004) 317-323.

[42] M.L. Gil-Cardeza, A. Ferri, P. Cornejo, E. Gomez, Distribution of chromium species in a Cr-polluted soil: presence of $\mathrm{Cr}(\mathrm{III})$ in glomalin related protein fraction, Sci. Total Environ. 493 (2014) 828-833.
[43] P.A. Olsson, A. Johansen, Lipid and fatty acid composition of hyphae and spores of arbuscular mycorrhizal fungi at different growth stages, Mycol. Res. 104 (2000) 429-434.

[44] P. Bonfante, R. Balestrini, K. Mendgen, Storage and secretion processes in the spore of gigaspora-margarita becker and hall as revealed by high-pressure freezing and freeze-substitution, New Phytol. 128 (1994) 93-101.

[45] W.W. Li, H.Q. Yu, Insight into the roles of microbial extracellular polymer substances in metal biosorption, Bioresour. Technol. 160 (2014) 15-23.

[46] T.T. More, J.S.S. Yadav, S. Yan, R.D. Tyagi, R.Y. Surampalli, Extracellular polymeric substances of bacteria and their potential environmental applications, J. Environ. Manage. 144 (2014) 1-25.

[47] H. Liu, H.H.P. Fang, Characterization of electrostatic binding sites of extracellular polymers by linear programming analysis of titration data, Biotechnol. Bioeng. 80 (2002) 806-811.

[48] D. Park, Y.S. Yun, J.M. Park, Comment on the removal mechanism of hexavalent chromium by biomaterials or biomaterial-based activated carbons, Ind. Eng. Chem. Res. 45 (2006) 2405-2407.

[49] T. Fukuda, Y. Ishino, A. Ogawa, K. Tsutsumi, H. Morita, Cr(VI) reduction from contaminated soils by Aspergillus sp N2 and Penicillium sp N3 isolated from chromium deposits, J. Gen. Appl. Microbiol. 54 (2008) 295-303.

[50] D.L. Arévalo-Rangel, J.F. Cárdenas-González, V.M. Martínez-Juárez, I Acosta-Rodríguez, Hexavalent chromate reductase activity in cell free extracts of Penicillium sp, Bioinorg. Chem. Appl. 2013 (2013) (Article ID 909412).

[51] N.T. Joutey, H. Sayel, W. Bahafid, N. El Ghachtouli, Mechanisms of hexavalent chromium resistance and removal by microorganisms, Rev. Environ. Contam. Toxicol. 233 (2015) 45-69.

[52] V. Karandashov, M. Bucher, Symbiotic phosphate transport in arbuscular mycorrhizas, Trends Plant Sci. 10 (2005) 22-29.

[53] Y. Kuga, K. Saito, K. Nayuki, R.L. Peterson, M. Saito, Ultrastructure of rapidly frozen and freeze-substituted germ tubes of an arbuscular mycorrhizal fungus and localization of polyphosphate, New Phytol. 178 (2008) 189-200.

[54] T. Ezawa, S.E. Smith, F.A. Smith, P metabolism and transport in AM fungi, Plant Soil 244 (2002) 221-230.

[55] S. Bajt, S. Clark, S. Sutton, M. Rivers, J. Smith, Synchrotron X-ray microprobe determination of chromate content using X-ray absorption near-edge structure, Anal. Chem. 65 (1993) 1800-1804.

[56] B. Degenhardt, H. Gimmler, Cell wall adaptations to multiple environmental stresses in maize roots, J. Exp. Bot. 51 (2000) 595-603.

[57] M. Krzeslowska, The cell wall in plant cell response to trace metals: polysaccharide remodeling and its role in defense strategy, Acta Physiol. Plant 33 (2011) 35-51.

[58] S.M. Macfie, P.M. Welbourn, The cell wall as a barrier to uptake of metal ions in the unicellular green alga Chlamydomonas reinhardtii (Chlorophyceae), Arch. Environ. Contam. Toxicol. 39 (2000) 413-419.

[59] L.Q. Lou, Z.G. Shen, X.D. Li, The copper tolerance mechanisms of Elsholtzia haichowensis, a plant from copper-enriched soils, Environ. Exp. Bot. 51 (2004) $111-120$.

[60] B.H. Ren, S.L. Wu, B.D. Chen, Z.X. Wu, X. Zhang, Cr stable isotope fractionation in arbuscular mycorrhizal dandelion and $\mathrm{Cr}$ uptake by extraradical mycelium, Pedosphere 25 (2015) 186-191.

[61] S.K. Das, A.K. Guha, Biosorption of hexavalent chromium by Termitomyces clypeatus biomass: kinetics and transmission electron microscopic study, J. Hazard. Mater. 167 (2009) 685-691. 